\title{
UPAYA MENINGKATKAN KETERAMPILAN MENULIS HURUF JAWA MELALUI DISKUSI KELOMPOK BERBANTU KARTU HURUF PADA PESERTA DIDIK KELAS VI SD 1 PRAMBATAN KIDUL KUDUS
}

\author{
Sulistyani \\ SD 1 Prambatan Kidul, Kecamatan Kaliwungu, Kabupaten Kudus \\ Email: sulistyani0608@gmail.com
}

\begin{tabular}{l}
\hline Info Artikel \\
\hline Sejarah Artikel: \\
Diserhakan 11 April 2020 \\
Direvisi 14 April 2020 \\
Direvisi 4 Mei 2020 \\
Disetujui 15 Mei 2020 \\
\hline Keywords: \\
writing the javanese script, \\
group discussion, \\
letter cards \\
\hline
\end{tabular}

\begin{abstract}
The study aims to improve the student skills in writing The Javanese Script and learning activities through group discussion assisted by letter cards in the 6th-grade students of SD 1 Prambatan Kidul Kudus Even Semester Academic Year 2018/2019.

This study is a Classroom Action Research (CAR) conducted in two cycles using The Javanese Script cards as the learning media and group discussion as the learning method. Research data were collected using nontest techniques (classroom observation, unstructured interviews, and documentation collection) and test techniques (individual written tests). Quantitative data were the scores of The Javanese Script writing skill were analyzed descriptively and qualitative data were the result of learning activities observations that converted into scores and categorized classically.

The Pre-cycle stage test score category consisted of poor (62.16\%) and fair scores (37.84\%), with students had reached learning mastery standard by $37.84 \%$. The Cycle I stage test score category consisted of poor (27.03\%), fair (56.76\%), and good scores $(16.22 \%)$, with students had reached learning mastery standard by $72.97 \%$. The Cycle II stage test score category consisted of fair (48.65\%), good (40.54\%), and very good scores $(10.81 \%)$, with students had reached learning mastery standard by $100 \%$. The classical learning activities observations are classified as good, both in Cycle I and Cycle II were $70.27 \%$ and $71.89 \%$, respectively. Thus, the method of group discussion assisted by letter cards is proven to improve the student skills in writing The Javanese Script and learning activities.
\end{abstract}

\begin{abstract}
Abstrak
Penelitian ini bertujuan untuk meningkatkan keterampilan menulis Aksara Jawa dan aktivitas belajar siswa melalui diskusi kelompok berbantu kartu huruf pada siswa kelas VI SD 1 Prambatan Kidul Kudus Semester Genap Tahun Pelajaran 2018/2019.

Penelitian ini merupakan Penelitian Tindakan Kelas (PTK) yang dilaksanakan dalam 2 siklus menggunakan kartu huruf Aksara Jawa sebagai media pembelajaran dan diskusi kelompok sebagai metode pembelajaran. Data penelitian dikumpulkan menggunakan teknik non tes (observasi kelas, wawancara tidak terstruktur, dan pengumpulan dokumentasi) dan teknik tes (tes tertulis secara individu). Data kuantitatif berupa nilai keterampilan menulis Aksara Jawa dianalisis secara deskriptif dan data kualitatif berupa hasil observasi aktivitas belajar dikonversi menjadi skor dan dikategorikan secara klasikal. Hasil kategori nilai tes tahap Prasiklus terdiri dari nilai kurang $(62,16 \%)$ dan cukup $(37,84 \%)$, dengan siswa mencapai ketuntasan belajar sebesar $37,84 \%$. Hasil kategori nilai tes tahap Siklus I terdiri dari nilai kurang $(27,03 \%)$, cukup $(56,76 \%)$, dan baik $(16,22 \%)$, dengan siswa mencapai ketuntasan belajar sebesar $72,97 \%$. Hasil kategori nilai tes tahap Siklus II terdiri dari nilai cukup $(48,65 \%)$, baik $(40,54 \%)$, dan sangat baik $(10,81 \%)$, dengan siswa mencapai ketuntasan belajar sebesar $100 \%$. Hasil pengamatan aktivitas belajar klasikal dikategorikan baik pada kedua siklus, yaitu 70,27\% (Siklus I) dan 71,89\% (Siklus I). Dengan demikian, metode diskusi kelompok berbantu kartu huruf terbukti mampu meningkatkan keterampilan menulis Aksara Jawa dan aktivitas belajar siswa.
\end{abstract}

(C) 2020 Universitas Muria Kudus 


\section{PENDAHULUAN}

Bahasa Jawa merupakan mata pelajaran wajib dalam Kurikulum Muatan Lokal pada jenjang Sekolah Dasar (SD) di Provinsi Jawa Tengah sebagai upaya melestarikan Budaya Jawa. Pembelajaran Bahasa Jawa ditujukan untuk membekali budi pekerti siswa melalui kemampuan berbahasa Jawa (Rahayu, 2014; Kurniati, 2015). Terdapat 4 (empat) aspek keterampilan dalam kemampuan berbahasa Jawa, meliputi mendengarkan (nyemak), berbicara (micara), membaca (maca), dan menulis (nulis). Penguasaan aspek-aspek tersebut memiliki tantangan dan kendala tersendiri bagi para siswa. Penyampaian materi Bahasa Jawa perlu diarahkan secara pragmatis agar pembelajaran menjadi lebih bermakna karena para siswa terbiasa menggunakan setiap aspek dengan baik dan benar (Fajarina, 2014). Penguasaan Bahasa Jawa juga dipengaruhi pengetahuan siswa tentang bagaimana menemukan kesalahan berbahasa Jawa, baik dalam pembelajaran maupun pemakaian seharihari (Hartati, 2013).

Salah satu aspek berbahasa Jawa yang sering menjadi momok adalah keterampilan menulis Aksara Jawa. Aksara Jawa merupakan salah satu sistem aksara tradisional yang muncul dan berkembang di Pulau Jawa yang digunakan secara umum untuk berbahasa Jawa dalam bentuk tulisan. Aksara Jawa termasuk jenis abugida (alfasilabis) dengan karakterkarakter aksara yang mewakili satu suku kata dengan notasi vokal (biasanya vokal "a") yang melekat pada setiap karakter dasar. Penulisan Aksara Jawa secara Alfabet Latin menggunakan satu (atau dua) huruf konsonan dan huruf vokal "a" (Anwari, 2017). Karakter dasar Aksara Jawa disebut juga Carakan terdiri dari 20 karakter yang masih murni dinamakan Aksara Jawa Nglegena atau Dhenta Wyanjana (Hadiwirodarsono, 2010). Setiap karakter Nglegena memiliki pendamping (Pasangan) untuk menulis gugus konsonan dari karakter utamanya (Darusuprapto dalam Rosidiyanti, 2018). Aksara Jawa juga mengenal Sandhangan yang merupakan karakter sejenis aksara yang tidak dapat berdiri sendiri dan berfungsi sebagai tanda yang selalu digunakan bersama dengan Aksara Nglegena (Achmad, 2017).

Kendala utama yang sering dihadapi adalah siswa sulit menghafal karakter-karakter Aksara Jawa beserta Pasangan dan Sandhangan. Akibatnya, siswa menjadi kurang cakap dalam menyusun Aksara Jawa menjadi kata atau kalimat (Astuti, 2016). Kondisi serupa juga ditemukan pada siswa kelas VI SD 1 Prambatan Kidul Semester Genap Tahun Pelajaran 2018/2019. Hasil observasi Prasiklus pada materi menulis Aksara Jawa menunjukkan siswa kelas masih menemui kesulitan dalam menuliskan kalimat menggunakan Aksara Jawa.

Kurangnya penguasaan siswa terhadap Aksara Jawa disebabkan karena Aksara Jawa jarang digunakan pada media literasi yang ditemui sehari-hari (Asriyani et al., 2012; Fajarina, 2014). Ketersediaan buku-buku bacaan sederhana yang ditulis menggunakan Aksara Jawa juga sangat kurang. Adapun buku-buku yang ada umumnya jauh di atas kompetensi penguasaan bahasa Jawa yang dimiliki siswa sekolah dasar. Di samping itu, pembelajaran menulis Aksara Jawa diintegrasikan dengan aspek keterampilan berbahasa Jawa yang lain dalam durasi tatap muka hanya 1-2 jam per minggu. Siswa cenderung diharuskan untuk mengingat bentuk dan aturan menulis Aksara Jawa tanpa memahami keuntungan mempelajari Aksara Jawa bagi mereka. Penguasaan guru terhadap materi Aksara Jawa yang hanya sebatas mengetahui dan mencontohkan dari buku pegangan atau Lembar Kerja Siswa (LKS) juga menjadi faktor yang mempersulit penguasaan Aksara Jawa oleh siswa. Kondisi tersebut terkadang diperparah dengan penggunaan media pembelajaran yang kurang menarik minat belajar siswa (Ekowati, 2012).

Antusiasme belajar yang rendah diduga menjadi penyebab siswa sulit menguasai keterampilan menulis Aksara Jawa. Metode pembelajaran yang tepat sangat diperlukan untuk meningkatkan hasil belajar dan motivasi siswa. Metode konvensional seperti ceramah dan menghafal mandiri membuat siswa merasa jenuh dan malas memperhatikan (Khoirurrozikin, 2010; Nurhidayati, 2011). Metode ceramah dapat diterapkan ketika siswa benar-benar memerlukan penjelasan, tidak tersedianya sumber materi pembelajaran, dan bila metode lain sulit diterapkan (Junairi, 2016). Meskipun demikian, metode ceramah idealnya digunakan dengan proporsi terkecil dari keseluruhan aktivitas belajar mengajar. Guru harus menentukan tujuan pembelajaran dari materi yang hendak disampaikan. Selanjutnya, melalui observasi yang terusmenerus, guru merumuskan langkah-langkah pembelajaran, isi pembelajaran, dan metode yang sesuai (Wiyoto, 2015). 
Suasana kelas yang dinamis dengan pengelolaan kelas yang efektif mendorong siswa dapat mengemukakan ekspresi dan pendapat dengan leluasa, tercipta suasana belajar yang menyenangkan, dan muncul antusiasme siswa dalam belajar. Pembiasaan berbahasa Jawa dapat diusahakan dengan mengurangi dominasi guru selama kegiatan belajar mengajar. Guru lebih berperan untuk mengarahkan dan memberikan motivasi sehingga siswa berani mengemukakan gagasan, bertanya, bahkan menyanggah melalui keterampilan berbicara dan menulis Jawa sejauh kemampuan siswa (Munawaroh, 2012).

Metode diskusi kelompok dapat meningkatkan aktivitas dan minat siswa selama mengikuti pembelajaran Bahasa Jawa (Wakhidah, 2016). Metode diskusi merupakan bentuk pendekatan pembelajaran aktif yang lebih menekankan siswa sebagai subjek. Metode diskusi kelompok sangat cocok diterapkan dalam pembelajaran agar siswa mampu menemukan dan memahami suatu pokok bahasan. Siswa dalam kelompok cenderung akan mendiskusikan dengan teman sebaya tentang kesulitan yang dihadapi dan mendorong pembelajaran berjalan secara kooperatif (Wiyoto, 2015). Hal tersebut memberikan siswa kesempatan untuk mengembangkan keterampilan pemecahan masalah sekaligus membiasakan siswa untuk berani terlibat aktif dan mengemukakan pendapat dalam kelompok (Sumarni et al., 2015).

Interaksi antara guru dengan siswa perlu diperlancar menggunakan media pembelajaran yang sesuai. Media pembelajaran bukan sebatas penyalur pesan dalam materi pembelajaran, tetapi juga harus dapat menumbuhkan atensi dan minat siswa dalam belajar (Mahnun, 2012). Penentuan media pembelajaran yang akan digunakan perlu memperhatikan tujuan pembelajaran, karakteristik siswa, bahan baku (ketersediaan bahan, kualitas, biaya pembuatan), dan penggunaan (efektivitas, fleksibilitas, kemampuan guru dalam menggunakan, alokasi waktu). Sebaik apapun media pembelajaran yang dibuat, hasil belajar tidak akan maksimal bila penggunaannya tidak sesuai dengan kondisi pembelajaran yang dihadapi.

Media pembelajaran dapat berupa media cetak, contoh display, audio, gambar bergerak, multimedia, dan media berbasis internet. Namun, tidak semua sekolah memiliki kemampuan untuk mengadakan semua bentuk media pembelajaran. Media sederhana pun dapat menjadi solusi bagi guru dalam pembelajaran (Worosetyaningsih et al., 2017). Penggunaan media pembelajaran dalam penyampaian materi menulis Aksara Jawa masih sangat minim. Media pembelajaran yang sering dijumpai adalah poster berisi Aksara Jawa yang ditempel di dinding kelas. Pemanfaatan media pembelajaran sederhana berupa kartu huruf mampu meningkatkan keterampilan menulis Aksara Jawa bagi siswa SD (Asriyani, et al., 2012; Tiarasari, 2013; Sari, 2014).

Penelitian ini bertujuan untuk meningkatkan keterampilan menulis Aksara Jawa dan aktivitas belajar siswa melalui diskusi kelompok berbantu kartu huruf pada siswa kelas VI SD 1 Prambatan Kidul Kudus Semester Genap Tahun Pelajaran 2018/2019. Penerapan metode pembelajaran dapat dimaksimalkan dengan media pembelajaran untuk mendukung efektivitas proses pembelajaran. Keterampilan menulis Aksara Jawa pada siswa kelas VI SD 1 Prambatan Kidul Kudus Semester Genap Tahun Pelajaran 2018/2019 menunjukkan kategori rata-rata nilai kurang dan terdapat sejumlah siswa yang belum memenuhi Kriteria Ketuntasan Minimal (KKM). Perbaikan perlu dilakukan dengan metode penyampaian materi dan penggunaan media pembelajaran. Penerapan metode diskusi berbantu media kartu huruf diharapkan mampu meningkatkan keterampilan menulis Aksara Jawa dan aktivitas belajar siswa.

\section{METODE PENELITIAN}

Penelitian ini merupakan Penelitian Tindakan Kelas (PTK) yang dilaksanakan dalam 2 (dua) siklus. Prasiklus merupakan hasil proses pembelajaran dengan metode ceramah. Siklus I dilakukan dengan metode diskusi kelompok menggunakan media pembelajaran berupa buku pegangan dan LKS. Siklus II dilakukan dengan metode diskusi kelompok berbantu media kartu huruf. Masingmasing siklus dilaksanakan dalam sekali pertemuan yang meliputi 4 (empat) tahapan, yaitu (1) perencanaan, (2) pelaksanaan, (3) observasi, dan (4) refleksi.

Penelitian dilaksanakan di SD 1 Prambatan Kidul, Kecamatan Kaliwungu, Kabupaten Kudus. Penelitian dilaksanakan pada Semester Genap Tahun Pelajaran 2018/2019. Subjek penelitian ini adalah seluruh siswa kelas VI SD 1 Prambatan Kidul berjumlah 37 siswa. Sedangkan, objek 
penelitian ini adalah keterampilan menulis Aksara Jawa yang meliputi ketepatan huruf, ketepatan Sandhangan, dan kerapian tulisan.

Media utama berupa kartu huruf Aksara Jawa (uk. $10 \mathrm{~cm} \times 7 \mathrm{~cm}$ ). Setiap kelompok mendapat 1 (satu) paket kartu berisi 32 kartu yang berbeda, terdiri dari 20 buah kartu Aksara Jawa Nglegena dan 12 buah kartu Sandhangan. Media pendukung berupa 1 (satu) paket kartu huruf Aksara Jawa (uk. $20 \mathrm{~cm} \times 14 \mathrm{~cm}$ ) sebagai media guru untuk mencontohkan penggunaan kartu huruf. Media pendukung lain adalah buku pegangan dan LKS sebagai sumber belajar. Karakter Aksara Jawa disajikan pada Gambar 1.

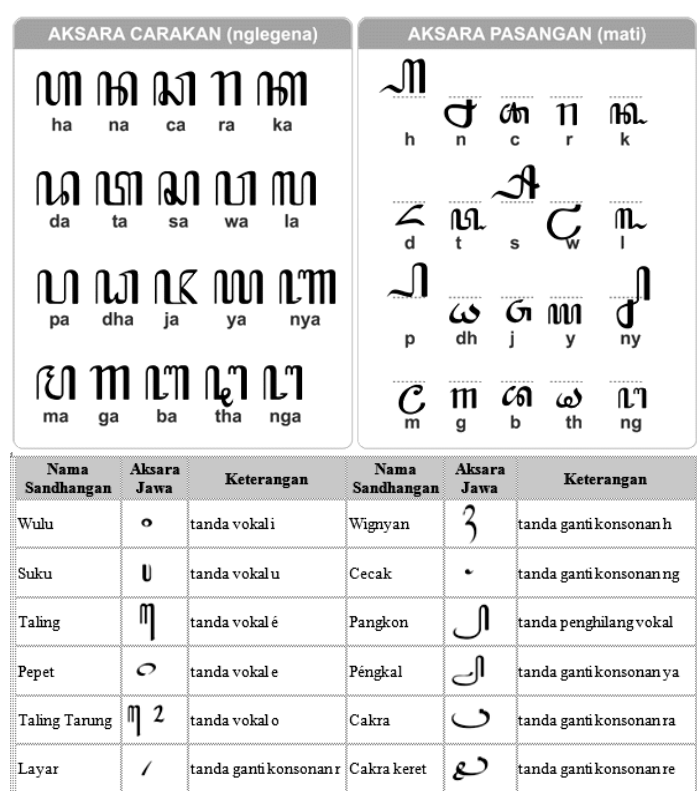

Gambar 1 Karakter Aksara Jawa Nglegena, Pasangan, dan Sandhangan

Sumber gambar:

a) https://hidupsimpel.com/aksara-jawa/

b) https://www.saferkidsandhomes.com/aksara-jawa/

Data dikumpulkan menggunakan teknik nontes dan tes. Teknik nontes meliputi observasi kelas, wawancara tidak terstruktur, dan pengumpulan dokumentasi. Observasi kelas dilakukan untuk mengukur aktivitas belajar oleh teman sejawat sebagai pengamat (observer). Indikator observasi meliputi: (1) kesiapan siswa dalam menerima pelajaran, (2) sikap siswa dalam menjawab pertanyaan dari guru/teman, (3) sikap siswa dalam memperhatikan penjelasan guru/teman, (4) sikap siswa dalam menanggapi masalah yang diajukan guru, dan (5) sikap siswa dalam menanggapi hasil diskusi. Wawancara tidak terstruktur dilakukan terhadap guru terkait penggunaan metode dan media pembelajaran serta kendala pembelajaran. Dokumentasi dilakukan dengan mengumpulkan hasil kerja siswa pada LKS untuk menganalisis kesulitan siswa dalam menulis Aksara Jawa. Teknik tes berupa tes tertulis menggunakan soal individu sebanyak 5 (lima) soal kalimat sederhana untuk mengukur peningkatan keterampilan menulis Aksara Jawa di setiap akhir siklus.

Variabel input yang dipilih adalah siswa kelas VI SD 1 Prambatan Kidul. Variabel proses yang ditentukan adalah metode diskusi kelompok berbantu media kartu huruf. Variabel output yang diamati berupa peningkatan keterampilan menulis Aksara Jawa dan aktivitas belajar siswa. Data kuantitatif berupa nilai keterampilan menulis Aksara Jawa dianalisis menggunakan analisis deskriptif untuk membandingkan rerata (mean) nilai sesuai Tabel 1. Tingkat ketuntasan belajar Bahasa Jawa dipatok berdasarkan Kriteria Ketuntasan Minimal (KKM), yaitu nilai 65.

Tabel 1. Kategori Nilai Keterampilan Menulis Aksara Jawa

\begin{tabular}{cc}
\hline Kategori & Rentang Nilai \\
\hline Sangat Baik & $85-100$ \\
Baik & $75-84$ \\
Cukup & $65-74$ \\
Kurang & $<65$ \\
\hline
\end{tabular}

Data kualitatif berupa hasil observasi aktivitas belajar siswa pada kedua siklus dikonversi menjadi skor (antara 1-4) dan dikategorikan secara klasikal sesuai Tabel 2.

Tabel 2. Kategori Skor Aktivitas Belajar Siswa

\begin{tabular}{cc}
\hline Kategori & Rentang Persentase Skor \\
\hline Sangat Baik & $85-100 \%$ \\
Baik & $65-84 \%$ \\
Cukup & $55-64 \%$ \\
Kurang & $<54 \%$ \\
\hline
\end{tabular}

\section{HASIL DAN PEMBAHASAN \\ Tahap Prasiklus}

Data Prasiklus diperoleh dari daftar nilai tes keterampilan menulis Aksara Jawa setelah guru menjelaskan dengan metode ceramah. Sebagian besar siswa belum menguasai keterampilan menulis Aksara Jawa berdasar pada tingginya persentase siswa yang mendapatkan nilai kategori kurang sebanyak $62,16 \%$. Siswa lainnya mendapat nilai kategori cukup sebanyak $37,84 \%$. Tidak terdapat siswa yang mendapatkan nilai kategori baik dan 
sangat baik. Nilai Tahap Prasiklus disajikan pada Gambar 2.

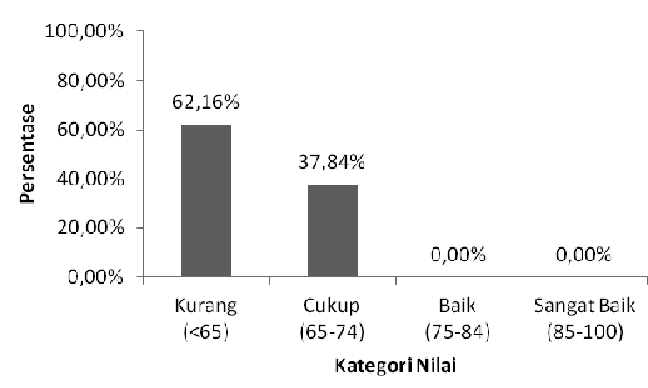

Gambar 2 Nilai Siswa pada Tahap Prasiklus

Ketuntasan belajar klasikal yang dicapai pada Tahap Prasiklus termasuk sangat rendah sebesar $37,84 \%$, dan sebanyak $62,16 \%$ siswa mendapat nilai di bawah nilai 65 yang merupakan batas nilai KKM. Berdasarkan hasil tersebut, metode ceramah kurang cocok untuk memberikan pemahaman pada siswa dalam menguasai keterampilan menulis Aksara Jawa. Metode lain perlu diterapkan untuk memperbaiki kekurangan dalam pembelajaran tersebut.

Metode ceramah sebenarnya bukan metode pembelajaran yang sepenuhnya buruk. Metode ceramah dapat memberikan gambaran yang detail pada siswa tentang bahan belajar. Namun, metode ceramah memiliki kekurangan karena siswa berpotensi merasa bosan. Guru perlu memperhitungkan waktu dan situasi pembelajaran ketika menggunakan metode ceramah sehingga diperoleh hasil belajar yang maksimal (Wiyoto, 2015).

Hasil penilaian tes pada Tahap Prasiklus diperkuat dengan hasil observasi bahwa siswa hanya mendengarkan guru menjelaskan tentang Aksara Jawa dilanjutkan mengerjakan soal pada LKS. Siswa umumnya merasa susah mengingat penjelasan guru sebelumnya. Siswa sangat lazim mengalami kesulitan belajar ketika hanya berbekal ingatan karena perkembangan anak memang belum terampil untuk menganalisis permasalahan yang bersifat abstrak (Sumantri dan Syaodih dalam Asriyani et al., 2012). Kesulitan siswa juga dikarenakan siswa belum terampil menerapkan kaidah penulisan, kurang berlatih menulis, dan kurang tertarik mempelajari Aksara Jawa (Anggraeni, 2013; Widayati, 2013; Widiwarti, 2013; Saputri, 2016).

Temuan tersebut membuktikan bahwa siswa perlu media bantu untuk mempermudah siswa memahami materi pembelajaran.
Berbagai media telah dikembangkan untuk menanggulangi kendala pembelajaran menulis Aksara Jawa seperti media permainan (Avianto dan Prasida, 2018; Wulandari, et al., 2018), media cerita bergambar (Nurhasanah, et al., 2014), bahkan media digital (Arismadhani, et al., 2013; Febriani, et al., 2015; Purwati, 2019). Media-media pembelajaran Bahasa Jawa tersebut diketahui membantu siswa memahami materi secara efektif. Namun, strategi pemilihan media perlu memperhatikan efisiensi sumber daya sekolah. Media pembelajaran sebisa mungkin dipilih karena relevansi terhadap materi, kelayakan operasional media, dan kemudahan pengadaan. Kondisi sekolah yang berbeda-beda, menuntut guru untuk kreatif mengembangkan media efektif sederhana yang layak digunakan dan mudah diproduksi (Prastya, 2016).

\section{Tahap Siklus I}

Data Siklus I diperoleh dari nilai tes keterampilan menulis Aksara Jawa setelah siswa menggunakan media pembelajaran berupa kartu huruf. Persentase siswa mendapatkan nilai kategori kurang turun menjadi 27,03\%. Persentase siswa mendapatkan nilai kategori cukup naik menjadi $56,76 \%$. Kemajuan pembelajaran tampak dengan adanya siswa yang mendapat nilai kategori baik sebanyak 16,22\%, meskipun belum ada siswa yang mendapat nilai kategori sangat baik. Nilai siswa pada tahap Siklus I disajikan pada Gambar 3.

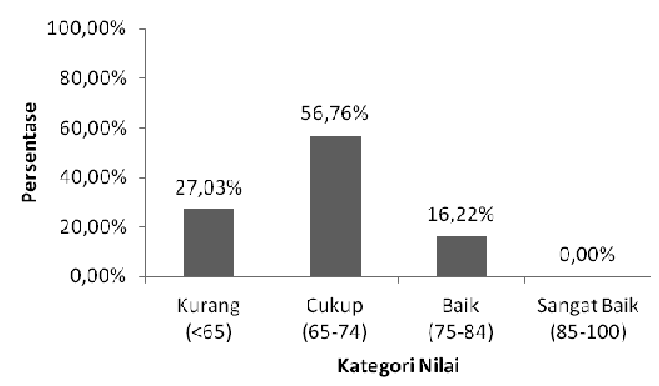

Gambar 3 Nilai Siswa pada Tahap Siklus I

Penggunaan media kartu huruf diketahui membantu siswa lebih memahami Aksara Jawa. Siswa diarahkan untuk mengalami sendiri proses memahami materi pembelajaran menggunakan media kartu huruf. Ketuntasan belajar klasikal yang dicapai pada Tahap Siklus I mulai membaik, yaitu $72,97 \%$ dan menyisakan $27,03 \%$ siswa yang belum tuntas. Penggunaan media kartu huruf mampu 
meningkatkan ketuntasan belajar klasikal, meskipun masih belum maksimal. Modifikasi perlu segera dilakukan untuk menunjang peningkatan tersebut agar dicapai hasil maksimal. Metode pembelajaran yang sesuai karakteristik kelas perlu diterapkan untuk mencapai ketuntasan belajar.

Media pembelajaran yang efektif memerlukan penggunaan yang tepat. Pemilihan media yang sesuai kebutuhan saja terkadang belum memberikan hasil maksimal karena penggunaan tidak dapat diterapkan secara tepat. Proses pembelajaran sehari-hari di sekolah tidak dapat hanya mengandalkan media pembelajaran saja. Berbagai kontribusi seperti metode, strategi, dan model pembelajaran serta karakteristik siswa perlu terintegrasi terhadap kondisi pembelajaran (Maimunah, 2016).

Hasil Siklus I menunjukkan penggunaan media pembelajaran saja masih dirasa kurang meningkatkan hasil belajar siswa. Sejumlah siswa dengan nilai <KKM menjadi pertimbangan guru untuk memperbaiki pembelajaran. Metode pembelajaran berkelompok diketahui dapat meningkatkan hasil belajar siswa. Salah satu metode yang mudah diterapkan secara klasikal adalah metode diskusi. Diskusi diterapkan untuk melibatkan semua siswa secara langsung, mengetahui pengetahuan dan pemahaman siswa terhadap materi, sekaligus menumbuhkan sikap ilmiah dan sosial siswa (Suryosubroto dalam Afandi, et al., 2013).

Penerapan metode diskusi pada berbagai mata pelajaran terbukti mampu meningkatkan hasil belajar individu maupun klasikal (Sumarni, et al., 2015; Wiyoto, 2015; Eliana, 2016; Itnawati, 2016; Rosmida, 2017). Pelaksanaan metode diskusi dimaksudkan agar siswa terdorong untuk aktif selama kegiatan belajar mengajar. Aktivitas siswa yang tinggi diperlihatkan dengan adanya ketertarikan siswa untuk membahas sekaligus menemukan solusi permasalahan pada materi secara bersama dalam kelompok. Guru bertindak sebagai fasilitator dan berkeliling mendatangi masingmasing kelompok untuk membantu berjalannya proses diskusi dan memberikan arahan bila kelompok mengalami kesulitan (Wiyoto, 2015).

\section{Tahap Siklus II}

Data Siklus II diperoleh dari nilai tes keterampilan menulis Aksara Jawa setelah siswa melakukan diskusi kelompok berbantu media kartu huruf. Hasil Siklus II menunjukkan bahwa tidak terdapat siswa yang mendapatkan nilai kategori kurang. Persentase siswa yang mendapatkan nilai kategori cukup sebanyak 48,65\%. Kemajuan pembelajaran tampak dari adanya siswa yang mendapat nilai kategori baik sebanyak 40,54\% dan kategori sangat baik sebanyak $10,81 \%$. Nilai siswa pada tahap Siklus II disajikan pada Gambar 4.

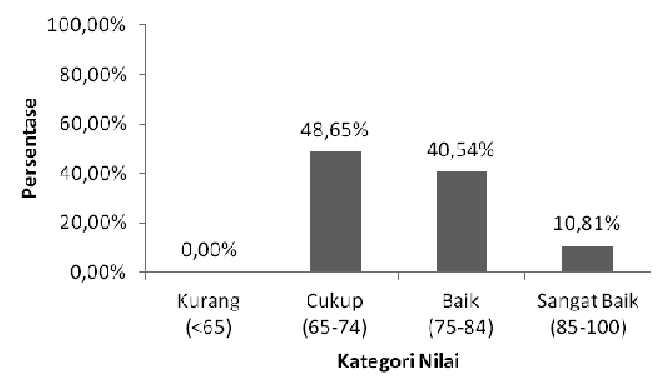

Gambar 4 Nilai Siswa pada Tahap Siklus II

Penerapan metode diskusi kelompok berbantu media kartu huruf membantu siswa lebih memahami Aksara Jawa. Ketuntasan belajar klasikal sudah mencapai $100 \%$, meskipun masih terdapat 3 siswa yang mendapatkan nilai 65 (nilai KKM). Hasil penelitian yang dilakukan memiliki persamaan dengan riset Fatmawati (2019) yang menunjukkan bahwa forum diskusi pada $e$ learning berbasis Moodle mampu meningkatkan partisipasi belajar mahasiswa jika dibandingkan dengan diskusi yang terjadi dikelas konvensional atau klasikal secara tatap muka dengan nilai peningkatan sebesar 37\%.

Selama pembelajaran pada Siklus II berlangsung, kelompok-kelompok kecil dibentuk untuk mendiskusikan pengetahuan yang telah diperoleh dengan teman-teman lain dalam kelompoknya. Evaluasi dilakukan melalui tes untuk mengetahui peningkatan keterampilan siswa secara individu maupun antarkelompok untuk memotivasi siswa bekerjasama secara kolektif dalam kelompoknya. Kompetisi antarkelompok memacu siswa untuk berbagi pengetahuan dan pemahaman tentang materi pembelajaran agar kelompoknya menjadi kelompok terbaik. Penerapan metode diskusi kelompok berbantu media kartu huruf mampu memenuhi kriteria ketuntasan belajar klasikal yang telah ditetapkan. Kombinasi metode dan media pembelajaran secara umum terbukti dapat diterapkan pada kegiatan pembelajaran guna 
meningkatkan hasil belajar hingga mencapai ketuntasan belajar.

\section{Kartu Huruf sebagai Alternatif Media Pembelajaran}

Media pembelajaran sebagai pengantar atau perantara informasi pembelajaran meliputi segala jenis sarana pendidikan yang dapat digunakan sebagai pengantar atau perantara dalam proses pembelajaran guna meningkatkan efektivitas dan efisiensi pencapaian tujuan pembelajaran secara instruksional. Hambatan yang sering muncul dalam pembelajaran secara klasikal antara lain perbedaan gaya belajar, minat belajar, tingkat kecerdasan, dan perbedaan daya ingat. Hal-hal tersebut menjadi penyebab kegagalan proses komunikasi atau penyampaian informasi selama pembelajaran. Terdapat potensi terjadinya perbedaan persepsi yang diterima siswa dalam pembelajaran. Media pembelajaran diperlukan untuk mengatasi hambatan tersebut. Guru perlu memiliki pengetahuan tentang media pembelajaran yang baik sehingga mampu menyesuaikan media pembelajaran terhadap karakteristik dan kondisi kelas serta kesulitan belajar yang dihadapi siswa (Rusydiyah, 2014).

Penggunaan media pembelajaran perlu memperhatikan kaidah ilmu komunikasi, "Who (says) What (to) Whom (in) Which Channel (with) What Effect". Kaidah tersebut dijabarkan menjadi model $5 \mathrm{~W}$, yaitu siapa pengirimnya (Who), apa yang ingin disampaikan (What), siapa penerimanya (Whom), sarana apa yang digunakan (Which Channel), dan dampak yang diinginkan (What Effect). Unsur-unsur tersebut menentukan efektivitas dan efisiensi penyampaian informasi (Lasswell dalam Wenxiu, 2015). Gambaran dampak yang diinginkan dalam kegiatan pembelajaran adalah siswa mendapatkan pengalaman belajar yang berkesan. Pengalaman belajar siswa dapat lebih bermakna ketika guru menggunakan media pembelajaran yang diminati siswa sekaligus sesuai dengan kebutuhan penyampaian materi pelajaran. Dengan demikian, siswa memperoleh pengalaman nyata terkait materi yang disampaikan sehingga siswa mudah menyerap dan memahami isi materi (Maimunah, 2016).

Salah satu alternatif media pembelajaran menulis adalah kartu huruf. Kelebihan media kartu huruf adalah mudah dibawa, disimpan, dan digunakan di mana saja, bahkan dikombinasikan dengan media lain. Selain itu, penggunaan kartu huruf sangat praktis karena tidak memerlukan keahlian khusus. Setiap lembar kartu huruf memiliki informasi berupa 1 (satu) karakter huruf saja, sehingga siswa mudah mengingat isi kartu. Media kartu dapat dikombinasikan dengan tanya jawab, diskusi, dan permainan agar timbul minat belajar karena pembelajaran berjalan menyenangkan (Asriyani, 2012).

Penelitian ini memiliki persamaan dengan penelitian Asriyani, et al. (2012), Tiarasari (2013), dan Sari (2014). Perbedaan penelitian ini dengan penelitian-penelitian terdapat pada modifikasi kartu huruf dan kombinasi penggunaannya dengan metode dan model yang berbeda. Penelitian Asriyani, et al. (2012) menggunakan kartu huruf dipadukan dengan model pembelajaran Quantum Teaching melalui permainan kartu. Penelitian Tiarasari (2013) menggunakan kartu huruf dipadukan dengan model pembelajaran Modeling The Way. Penelitian Sari (2014) menggunakan kartu huruf berbahan kain flannel dipadukan dengan metode ceramah dan diskusi kelas. Adapun penelitian ini menekankan penggunaan kartu huruf dipadukan dengan proses elaborasi mandiri oleh siswa dalam diskusi kelompok dan pemberian motivasi melalui kompetisi antarkelompok.

\section{Diskusi sebagai Metode Pembelajaran}

Diskusi sebagai percakapan ilmiah diperlukan untuk bertukar pendapat, mencari solusi, mendapatkan jawaban, dan kebenaran atas suatu masalah (Suryosubroto dalam Afandi, et al., 2013). Diskusi berjalan melalui suatu percakapan ilmiah yang responsif terhadap pertanyaan-pertanyaan yang bersifat problematis terkait pemunculan atau pengujian suatu ide yang dibahas (Sagala, 2017). Diskusi dapat diterapkan dalam kegiatan pembelajaran di sekolah. Siswa diajak untuk membicarakan masalah terkait materi pembelajaran dan menemukan solusi secara bersama-sama. Diskusi sebagai sebuah metode pembelajaran bertujuan untuk berbagi ilmu pengetahuan dan peran dalam kelompok dalam menemukan kebenaran belajar secara kolektif. Diskusi melatih setiap siswa ikut berfikir ilmiah berdasarkan data dan fakta yang dimiliki dan diperlukan kedisiplinan agar diskusi berjalan dengan baik (Afandi, et al., 2013).

Metode diskusi sebagai salah satu jenis aktivitas belajar siswa dalam pembelajaran perlu dilakukan secara sistematis. Guru sebagai fasilitator perlu merumuskan masalah secara 
jelas dan mengarahkan siswa dalam proses membentuk kelompok-kelompok diskusi beserta kelengkapannya. Diskusi dibimbing dan diawasi oleh guru agar tetap terkendali. Guru perlu melakukan langkah-langkah untuk memotivasi siswa sehingga semua merasa terlibat dan berperan aktif dalam kelompok masing-masing. Hasil diskusi dicatat oleh seluruh anggota kelompok dengan baik dan sistematis untuk kemudian disampaikan di depan kelas oleh perwakilan kelompok. Pada akhir diskusi, guru memberi penguatan terhadap hasil diskusi masing-masing kelompok dan menilai pelaksanaan diskusi sebagai bahan refleksi dan perbaikan pada aktivitas diskusi selanjutnya (Djamarah dan Zain, 2010; Sudjana, 2017).

\section{Peningkatan Hasil Belajar dan Aktivitas Belajar Siswa}

Hasil penelitian menunjukkan terdapat peningkatan pada keterampilan siswa dalam menulis Aksara Jawa. Keterampilan siswa yang meningkat tersebut merupakan indikator adanya kemajuan hasil belajar dari siklus ke siklus pada penelitian ini. Hal tersebut dapat diketahui dengan membandingkan rerata (mean) nilai dan ketuntasan belajar klasikal pada masing-masing siklus yang disajikan pada Gambar 5.

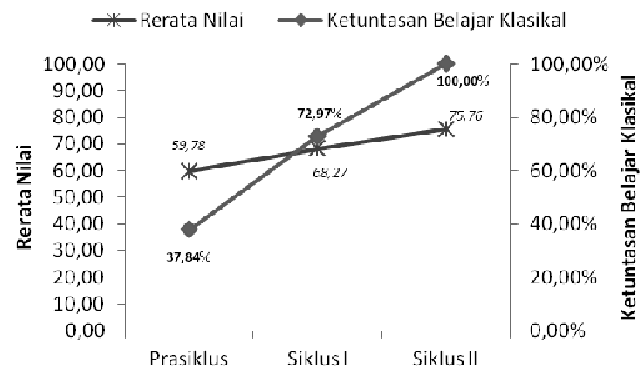

Gambar 5 Peningkatan Keterampilan Siswa dalam Menulis Aksara Jawa

Peningkatan hasil belajar dicapai melalui perbaikan pembelajaran yang dilakukan pada Siklus I dan II. Secara umum, keberhasilan pembelajaran tampak pada nilai siswa yang semakin baik dan hasil ketuntasan klasikal. Meskipun demikian, guru sebagai pendidik perlu mencermati apakah hasil tersebut juga merupakan keberhasilan pembelajaran secara proses atau hanya sebatas nilai saja. Keberhasilan pembelajaran secara proses tampak pada aktivitas siswa selama mengikuti pembelajaran. Aktivitas belajar siswa hendaknya perlu dilakukan dengan penuh kesadaran dan kesungguhan serta siswa dapat menemukan perasaan menyenangkan yang memunculkan minat belajar. Dengan demikian, kegiatan pembelajaran tidak hanya sebatas rutinitas, sehingga proses pencarian ilmu pengetahuan dan pemecahan masalah pembelajaran menjadi lebih bermakna (Sudjana dalam Afandi, et al., 2013).

Selama proses pembelajaran pada Siklus I dan II berlangsung, kegiatan siswa diamati oleh teman sejawat sebagai pengamat (observer). Teknis observasi dilakukan dengan memperhatikan indikator observasi yang telah ditetapkan. Observasi ditujukan untuk mengamati sikap siswa sebelum, selama, dan setelah mengikuti pembelajaran. Hasil pengamatan aktivitas belajar siswa menunjukkan bahwa kategori aktivitas belajar secara klasikal pada Siklus I dan II tergolong baik (65-84\%). Aktivitas belajar pada Silkus I $(70,27 \%)$ meningkat sebesar $1,62 \%$ lebih baik pada Siklus II $(71,89 \%)$. Aktivitas belajar siswa pada tahap Siklus I dan II disajikan pada Gambar 6.

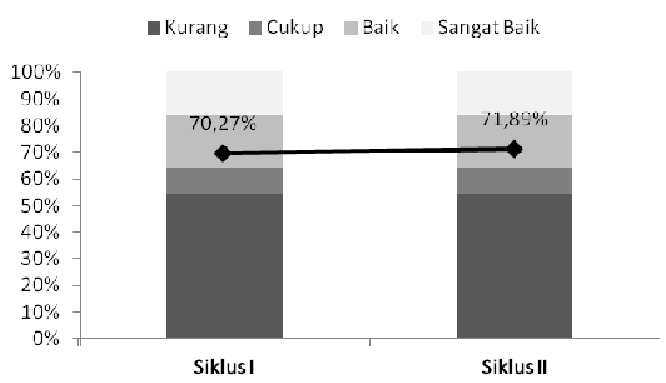

Gambar 6 Aktivitas Belajar Siswa

Hasil pengamatan terhadap aktivitas belajar siswa pada Siklus I dan II menunjukkan bahwa keberhasilan pembelajaran secara proses telah terpenuhi dengan kategori baik. Aspek pengamatan mencakup sikap, nilai-nilai, dan minat siswa saat mengikuti pembelajaran. Hasil pengamatan secara umum terlihat bahwa siswa siap menerima pelajaran. Siswa pun mencoba untuk mencari dan menyampaikan jawaban dari pertanyaan yang diajukan oleh guru/teman dan memperhatikan penjelasan materi yang disampaikan oleh guru/teman. Siswa juga terlibat dalam memberikan tanggapan terhadap permasalahan yang dimunculkan oleh guru, dan memberikan pendapat pada hasil diskusi dari kelompoknya sendiri maupun kelompok lain. Dengan demikian, aktivitas belajar siswa telah menunjukkan adanya kesadaran, kesungguhan, dan minat belajar. Peningkatan hasil belajar disertai dengan aktivitas belajar 
yang baik merupakan indikator keberhasilan pembelajaran yang ingin dicapai pada penelitian ini.

Hasil penelitian yang dilakukan memiliki persamaan dan perbedaan dengan riset Roysa (2014), penelitian Hastutik (2015), riset Supriyati (2015), penelitian Ahsin (2016) dan riset Mulyono (2018). Persamaan yang dimaksud yaitu pada topik riset yang dipilih yakni mengenai keterampilan menulis dan Bahasa Jawa sebagai mata pelajaran yang menjadi fokus. Adapun hasil penelitiannya berbeda satu sama lain.

Riset Roysa (2014) menyimpulkan bahwa (1) model pengajaran tidak langsung cocok untuk pembelajaran kemampuan menulis cerpen dilihat dari siswa yang tingkat kemandirian tinggi dan (2) model kooperatif integratif cocok untuk pembelajaran menulis cerpen dilihat dari siswa yang memiliki tingkat kemandirian rendah. Sementara itu penelitian Ahsin (2016) menemukan bahwa (1) Penggunaan media audiovisual dan metode pembelajaran quantum learning dapat meningkatkan kualitas proses pembelajaran menulis narasi pada siswa kelas XA MATBS Kudus, (2) penggunaan media audiovisual dan metode quantum learning dapat meningkatkan keterampilan menulis narasi di kelas XA MA TBS Kudus. Hal ini dapat dilihat dengan peningkatan keaktifan siswa, minat siswa dalam pembelajaran meningkat, serta kemandirian siswa meningkat saat menulis narasi. Selain itu, nilai rata-rata siswa juga terbukti mengalami peningkatan dari siklus pertama ke siklus. Kemampuan untuk menulis karangan narasi siswa meningkat, nilai rata-rata siklus I 73,46, sedangkan pada siklus II meningkat menjadi 80,89. Lebih lanjut riset Mulyono (2018) menyimpulkan bahwa Pemberdayaan foto hasil kunjungan wisata sebagai media menulis karangan deskripsi dapat meningkatkan minat dan keterampilan belajar siswa kelas IV SD 5 Lau semester genap tahun 2016/2017

Penelitian

Hastutik

(2015)

menyimpulkan bahwa peningkatan kualitas pembelajaran baik proses maupun hasil membaca aksara Jawa pada peserta didik kelas 3 SD 2 Honggosoco Kecamatan Jekulo Kabupaten Kudus. Peningkatan kualitas proses pembelajaran tersebut ditandai dengan meningkatnya: 1) jumlah kualitas peserta didik yang aktif dalam kegiatan apersepsi maupun dalam kegiatan pembelajaran; 2) jumlah peserta didik yang tertarik dan termotivasi dalam kegiatan pembelajaran membaca aksara Jawa; dan 3) jumlah peserta didik yang sudah mampu membaca aksara Jawa dengan teknik yang benar dengan menggunakan metode lawaran.

Riset Supriyati (2015) menemukan bahwa pembelajaran berbahasa Jawa dengan metode bermain peran dalam pembelajaran terjadi peningkatan minat $57,9 \% \quad(31,58 \%$ menjadi $89,48 \%)$, keberanian $68,42 \%(26,32 \%$ menjadi $94,74 \%)$, peran $57,90 \% \quad(31,58 \%$ menjadi $89,48 \%)$, kemampuan $78,95 \%$ (10,53\% menjadi 89,48\%).Dengan demikian dapat disimpulkan bahwa minat, keberanian, peran, serta kemampuan berbahasa Jawa peserta didik dapat ditingkatkan melalui metode bermain peran.

\section{SIMPULAN}

Metode diskusi kelompok berbantu kartu huruf terbukti mampu meningkatkan keterampilan menulis Aksara Jawa dan aktivitas belajar pada siswa kelas VI SD 1 Prambatan Kidul Kudus Semester Genap Tahun Pelajaran 2018/2019. Keterampilan siswa dalam menulis Aksara Jawa mengalami peningkatan dari rerata (mean) nilai Prasiklus sebesar 59,78, meningkat pada Siklus I sebesar 68,27, dan meningkat lagi pada Siklus II sebesar 75,76. Ketuntasan belajar klasikal mengalami peningkatan dari persentase ketuntasan Prasiklus sebesar 37,84\%, meningkat pada Siklus I sebesar $72,97 \%$, dan meningkat lagi pada Siklus II sebesar $100 \%$. Keberhasilan pembelajaran secara proses tampak pada aktivitas siswa selama mengikuti pembelajaran. Hasil pengamatan aktivitas belajar siswa secara klasikal Siklus I sebesar $70,27 \%$ dan Siklus II sebesar 71,89\%. Hasil tersebut tergolong pada kategori aktivitas belajar siswa secara klasikal yang baik (65$84 \%)$.

\section{DAFTAR PUSTAKA}

Achmad, S. W. 2017. Filsafat Jawa: Menguak Filosofi, Ajaran, dan Laku Hidup Leluhur Jawa. Sleman: Araska Publisher.

Afandi, M., Chalamah, E., dan Wardani, O. P. 2013. Model dan Metode Pembelajaran di Sekolah. Semarang: UNISSULA Press. 
Ahsin, Muhammad Nur. 2016. Peningkatan Keterampilan Menulis Karangan Narasi Dengan Menggunakan Media Audiovisual Dan Metode Quantum Learning. Refleksi Edukatika : Jurnal Ilmiah Kependidikan, 6 (2): 158-171.

Anggraeni, P. 2013. Mengatasi Kesulitan Menulis Aksara Jawa Siswa Kelas IV SD Negeri 03 Batangsaren Kabupaten Tulungagung dengan Menggunakan Media Papan Flanel (Skripsi). Malang: Fakultas Sastra Universitas Negeri Malang.

Anwari, B. 2017. Baboning Pepak Basa Jawa. Sidoarjo: Genta Group Production.

Arismadhani, A., Yuhana, U. L., dan Kuswadayan, I. 2013. Aplikasi Belajar Menulis Aksara Jawa Menggunakan Android. Jurnal Teknik Pomits, 2 (1), 9498.

Asriyani, Nugraheni, E. S., Ayuningtyas, K., Wahyudi, dan Suyanto, I. 2012. Penggunaan Media Kartu Huruf dalam Pembelajaran Aksara Jawa di Sekolah Dasar. Kalam Cendekia, 1 (2): 34-39.

Astuti, S. P. 2016. Pengaruh Penggunaan Media Pembelajaran Dadu Aksara Jawa terhadap Keterampilan Menulis Aksara Jawa di Kelas IV SD Negeri Bangunharjo (Skripsi). Yogyakarta: Fakultas Ilmu Pendidikan Universitas Negeri Yogyakarta.

Avianto, Y. F. dan Prasida, T. A. S. 2018. Pembelajaran Aksara Jawa untuk Siswa Sekolah Dasar dengan Menggunakan Media Board Game. Jurnal Aksara, 30 (1): 133-148.

Djamarah, S. B. dan Zain, A. 2010. Strategi Belajar Mengajar. Jakarta: Rineka Cipta.

Ekowati, VI. 2012. Javanese Letters: Symbols of Javanese Civilization: (Introduction, History, Philosophical Values, Learning Methods, Utilizations, Touch Of Technology in Javanese Letters). Prosiding $1^{\text {st }}$ Mae Fah Luang University International Conference 2012, 1-10.

Eliana. 2016. Pembelajaran Bahasa Jawa dan Implementasinya dalam Kehidupan
Sehari-hari pada Murid Sekolah Dasar Kelas Satu dan Kelas Dua dari Suku Bangsa Madura di Sekolah Dasar Negeri Pegirian I/47, Jl. Wonosari I/16, Kecamatan Semampir, Kota Surabaya. Jurnal AntroUnairdotNet, 5 (2): 278-287.

Fajarina, D. S. N. 2014. Pangrembakane Media Animasi Gambar Ing Pasinaon Nyemak Crita Cekak Siswa Kelas VII SMP Negeri 3 Nganjuk Taun Ajaran 2012/2013. Jurnal Baradha, 2 (2): 1-9.

Fatmawati Soraya. 2019. Efektivitas Forum Diskusi Pada E-Learning Berbasis Moodle Untuk Meningkatkan Partisipasi Belajar. Refleksi Edukatika : Jurnal Ilmiah Kependidikan, 9 (2): 210-216.

Febriani, R., Prabowo, H., dan Mardiyono. 2015. Game Puzzle Bahasa Jawa Berbasis Table PC Android. Jurnal Sinergi, 19 (2), 146-152.

Hadiwirodarsono, S. 2010. Belajar Membaca dan Menulis Aksara Jawa. Solo: Kharisma.

Hartati, D. D. 2013. Analisis Salahe Basa Sajrone Karangane Siswa Kelas VII E SMP Negeri 6 Surabaya Taun Ajaran 2012/2013. Jurnal Baradha, 1 (3): 1-7.

Hastutik, Sri. 2015. Penerapan Metode Lawaran Untuk Meningkatkan Keterampilan Dan Motivasi Membaca Huruf Jawa Pada Peserta Didik Kelas 3 Sd 2 Honggosoco Kecamatan Jekulo Kabupaten Kudus Tahun Pelajaran 2014/2015. Refleksi Edukatika : Jurnal Ilmiah Kependidikan, 5 (2).

Itnawati. 2016. Metode Diskusi dalam Meningkatkan Hasil Belajar Siswa pada Pembelajaran Matematika di Sekolah Dasar. Suara Guru: Jurnal Ilmu Pendidikan Sosial, sains, dan Humaniora, 2 (3): 277-282.

Junairi. 2016. Efektivitas Metode Ceramah dengan Multi Media dan Metode Ceramah tanpa Multi Media terhadap Pembelajaran Ilmu Pengetahuan Sosial (IPS) pada Hasil Belajar Siswa Kelas V Madrasah Ibtidaiyah (MI) se Kecamatan Ringinrejo 
Kab. Kediri (Tesis). Tulungagung: Pascasarjana IAIN Tulungagung.

Khoirurrozikin, M. I. 2010. Penggunaan Media Kartu Huruf dalam Pembelajaran Aksara Jawa sebagai Upaya Peningkatan Motivasi Belajar Siswa Kelas II SDN Torongrejo 02 Kota Batu (Skripsi). Malang: Fakultas Tarbiyah Universitas Islam Negeri Maulana Malik Ibrahim Malang.

Kurniati, E. 2015. Implementasi Pembelajaran Bahasa Jawa SD yang Integratif Komunikatif Berbasis Folklore Lisan sebagai Wujud Konservasi Budaya. Jurnal Penelitian Pendidikan, 32 (2): 107-118.

Mahnun N. 2012. Media Pembelajaran (Kajian terhadap Langkah-langkah Pemilihan Media dan Implementasinya dalam Pembelajaran). Jurnal Pemikiran Islam, 37 (1): 27-35.

Maimunah. 2016. Metode Penggunaan Media Pembelajaran. Jurnal Al-Afkar, 5 (1), 1-24.

Mulyono. 2018. Pemberdayaan Foto Wisata Untuk Peningkatkan Minat Dan Keterampilan Menulis Deskripsi Pada Siswa Kelas Iv Sd 5 Lau. Refleksi Edukatika : Jurnal Ilmiah Kependidikan, 8 (2): 124-131.

Munawaroh, I. 2012. Esensi "Menghidupkan" Ruang Kelas bagi Penyelenggaraan Pembelajaran Efektif. Majalah Ilmiah Pembelajaran, edisi khusus, 36-50.

Nurhasanah, Wurianto, A. B., dan Arifin, B. 2014. Pengembangan Media Kijank (Komik Indonesia, Jawa, dan Aksara Jawa) Pembelajaran Bahasa Jawa Kelas 5 Sekolah Dasar. Jurnal Pemikiran dan Pengembangan SD, 1 (4), 267-273.

Nurhidayati, 2011. Metode Pembelajaran Interaktif. Prosiding Seminar Metode Pembelajaran KKN-PPL Universitas Negeri Yogyakarta-SMP N 2 Depok Tahun 2011, 1-15.

Prastya, A. 2016. Strategi Pemilihan Media Pembelajaran bagi Seorang Guru. Prosiding Temu Ilmiah Nasional Guru (TING) VIII, 294-302.
Purwati. 2019. Peningkatan Hasil Belajar Bahasa Jawa Materi Menulis Karangan Cerita Peristiwa Alam dengan Media Power Point pada Siswa Kelas V SD. Dwija Cendekia: Jurnal Riset Pedagogik, 3 (1), 1-10.

Rahayu, S. 2014. Pelajaran Bahasa Jawa Sebuah Retrospeksi dan Prospeksi. Jurnal Ilmiah WUNY, 16 (2): 1-8.

Rosidiyanti, H. M. 2018. Perancangan Buku Ilustrasi Aksara Jawa dengan Teknik Digital Vektor sebagai Media Pembelajaran Anak Kelas 3 Sekolah Dasar (Skripsi). Surabaya: Fakultas Teknologi dan Informatika Institut Bisnis dan Informasi Stikom Surabaya.

Rosmida. 2017. Penerapan Metode Diskusi untuk Meningkatkan Hasil Belajar IPS Siswa Kelas VA SD Negeri 004 Tembilahan Kecamatan Tembilahan Kabupaten Indragiri Hilir. Jurnal Primary FKIP Universitas Riau, 6 (1): 296-305.

Roysa, Mila. 2014. Kemampuan Menulis Cerpen Dengan Perlakuan Model Pengajaran Tidak Langsung dan Model Kooperatif Integratif Pada Siswa Sma Dilihat Dari Tingkat Kemandirian Siswa. Refleksi Edukatika : Jurnal Ilmiah Kependidikan, 4 (2): 1-13.

Rusydiyah, E. F. 2014. Media Pembelajaran. Surabaya: UINSA Press.

Sagala, S. 2017. Konsep dan Makna Pembelajaran. Bandung: Alfabeta.

Saputri, K. R. 2016. Analisis Kesalahan Menulis Aksara Jawa Berbasis KTSP pada Siswa Kelas V SDN Se-kecamatan Kaliwungu, Kabupaten Kudus (Skripsi). Semarang: Fakultas Ilmu Pendidikan Universitas Negeri Semarang.

Sari, D. D. 2014. Peningkatan Keterampilan Menulis Aksara Jawa Melalui Model Pembelajaran Quantum Teaching dengan Permainan Kartu Huruf pada Siswa Kelas III SDN Tunggulsari I No. 72 Surakarta Tahun Pelajaran 2013/2014 (Skripsi). Surakarta: Fakultas Keguruan dan Ilmu Pendidikan Universitas Muhammadiyah Surakarta. 
Sudjana, N. 2017. Dasar-Dasar Proses Belajar Mengajar. Bandung: Sinar Baru Algensindo.

Sumarni, Harun, A. H., dan Imran. 2015. Penerapan Metode Diskusi Untuk Meningkatkan Hasil Belajar Siswa Kelas IV Sekolah Dasar Kecil Toraranga Pada Mata Pelajaran PKn Pokok Bahasan Sistem Pemerintahan Kabupaten, Kota dan Provinsi. Jurnal Kreatif Online, 3 (4): 13-22.

Supriyati. 2015. Metode Bermain Peran Sebagai Upaya Meningkatkan Kemampuan Berbahasa Jawa Pada Peserta Didik Kelas 6 SD 5 Hadipolo Kecamatan Jekulo Kabupaten Kudus Semester 1 Tahun Pelajaran 2014/2015. Refleksi Edukatika : Jurnal Ilmiah Kependidikan, 5 (2).

Tiarasari, A. W. 2013. Peningkatan Keterampilan Menulis Aksara Jawa melalui Modeling The Way dengan Media Flashcard Pada Siswa Kelas IV SDN Mangkangkulon 01 Semarang (Skripsi). Semarang: Fakultas Ilmu Pendidikan Universitas Negeri Semarang.

Wakhidah. 2016. Peningkatkan Motivasi dan Hasil Belajar Siswa Melalui Metode Diskusi Kelompok pada Pembelajaran Bahasa Jawa Kelas VI SD Negeri 03 Pojok Karanganyar. Jurnal Teknologi Pendidikan, 1 (2): 1-9.
Wenxiu, P. 2015. Analysis of New Media Communication Based on Lasswell's "5W" Model. Journal of Educational and Social Research, 5 (3): 245-250.

Widayati, T. 2013. Analisis Kesalahan Menulis Wacana BerAksara Jawa Siswa Kelas X di SMK YPKK 2 Sleman (Skripsi). Yogyakarta: Fakultas Bahasa dan Seni Universitas Negeri Yogyakarta.

Widiwarti, S. 2013. Kendala-kendala Menulis Aksara Jawa di SMP Negeri Malang (Skripsi). Malang: Fakultas Sastra Universitas Negeri Malang.

Wiyoto A. 2015. Peningkatan Motivasi dan Prestasi Belajar Bahasa Jawa pada Siswa Kelas IX-D MTSn Kampak Trenggalek Menerapkan Pembelajaran Dengan Multi Metode. Jurnal Pendidikan Profesional, 4 (2): 190-201.

Worosetyaningsih T, Rahmawati F, dan Sugiarto. 2017. Panduan Pengembangan Media Pembelajaran Sederhana. Jakarta: Direktorat Pendidikan Dasar dan Menengah Kementerian Pendidikan dan Kebudayaan.

Wulandari, Y. D., Poerwanti, E., dan Isbadrianingtyas, N. 2018. Pengembangan Media Perdasawa (Permainan Dakon Aksara Jawa) Mata Pelajaran Bahasa Jawa pada Kelas V Sekolah Dasar. Jurnal Pemikiran dan Pengembangan SD, 6 (1), 75-87. 